\title{
Molecular Variants and Their Risks for Malignancy in Cytologically Indeterminate Thyroid Nodules
}

\author{
Whitney S. Goldner, ${ }^{1}$ Trevor E. Angell, ${ }^{2}$ Sallie Lou McAdoo, ${ }^{3}$ Joshua Babiarz,, \\ Peter M. Sadow, ${ }^{4-6}$ Fadi A. Nabhan, ${ }^{7}$ Christian Nasr, ${ }^{8}$ and Richard T. Kloos ${ }^{3}$
}

Background: Gene panels are routinely used to assess predisposition to hereditary cancers by simultaneously testing multiple susceptibility genes and/or variants. More recently, genetic panels have been implemented as part of solid tumor malignancy testing assessing somatic alterations. One example is targeted variant panels for thyroid nodules that are not conclusively malignant or benign upon fine-needle aspiration (FNA). We systematically reviewed published studies from 2009 to 2018 that contained genetic data from preoperative FNA specimens on cytologically indeterminate thyroid nodules (ITNs) that subsequently underwent surgical resection. Pooled prevalence estimates per gene and variant, along with their respective positive predictive values (PPVs) for malignancy, were calculated. Summary: Our systematic search identified 540 studies that were supplemented by 18 studies from bibliographies or personal files. Sixty-one studies met all inclusion criteria and included $>4600$ ITNs. Overall, $26 \%$ of nodules contained at least 1 variant or fusion. However, half of them did not include details on the specific gene, variant, and/or complete fusion pair reported for inclusion toward PPV calculations. The PPVs of genomic alterations reported at least 10 times were limited to $B R A F^{V 600 E}$ (98\%, 95\% confidence interval [CI 96-99\%]), PAX8/ PPARG (55\% [CI 34-78\%]), HRAS $S^{Q 61 R}$ (45\% [CI 22-72\%]), BRAF ${ }^{K 601 E}$ (42\% [CI 19-68\%]), and NRAS (38\% [CI 23-55\%]). Excluding $B R A F^{V 600 E}$, the pooled PPV for all other specified variants and fusions was $47 \%$. Multiple variants within the same nodule were identified in $\sim 1 \%$ of ITN and carried a cumulative PPV of $77 \%$. Conclusions: The chance that a genomic alteration predicts malignancy depends on the individual variant or fusion detected. Only five alterations were reported at least 10 times; $B R A F^{V E O O E}$ had a PPV of $98 \%$, while the remaining four had individual PPVs ranging from $38 \%$ to $55 \%$. The small sample size of most variants and fusion pairs found among ITNs, however, limits confidence in their individual PPV point estimates. Better specific reporting of genomic alterations with cytological category, histological subtype, and cancer staging would facilitate better understanding of cancer prediction, and the independent contribution of the genomic profile to prognosis.

Keywords: thyroid nodule, molecular testing, fine-needle aspiration, molecular diagnostics, indeterminate cytology, thyroid cancer

\section{Introduction}

T HE PREDICTION OF MALIGNANCY in thyroid nodules continues to evolve. Sonographic characteristics of thyroid nodules alone are not sufficient to predict the risk of malig- nancy for many nodules $(1,2)$. Thyroid nodule fine-needle aspiration (FNA) is routinely performed to cytologically evaluate thyroid nodules that meet certain sonographic criteria $(3,4)$. Management of nodules whose cytology is not clearly benign or malignant has been the most challenging. In

\footnotetext{
${ }^{1}$ Division of Diabetes, Endocrinology, and Metabolism, Department of Internal Medicine, University of Nebraska Medical Center, Omaha, Nebraska.

${ }^{2}$ Division of Endocrinology, Diabetes and Metabolism, Keck School of Medicine, University of Southern California, Los Angles, California.

${ }^{3}$ Veracyte, Inc., South San Francisco, California.

${ }^{4}$ Pathology Service, Massachusetts General Hospital, Boston, Massachusetts.

${ }^{5}$ Department of Pathology, Harvard Medical School, Boston, Massachusetts.

${ }^{6}$ Department of Otolaryngology, Massachusetts Eye and Ear, Boston, Massachusetts.

${ }^{7}$ Division of Endocrinology, Diabetes, and Metabolism, The Ohio State University Wexner Medical Center and Arthur G. James Cancer Center, Columbus, Ohio.

${ }^{8}$ Endocrinology and Metabolism Institute, Cleveland Clinic Foundation, Cleveland, Ohio.

(C) Whitney S. Goldner et al. 2019; Published by Mary Ann Liebert, Inc. This Open Access article is distributed under the terms of the Creative Commons License (http://creativecommons.org/licenses/by/4.0), which permits unrestricted use, distribution, and reproduction in any medium, provided the original work is properly cited.
} 
the Bethesda System for Reporting Thyroid Cytopathology, the indeterminate categories of AUS/FLUS (atypia of undetermined significance [AUS] or follicular lesion of undetermined significance [FLUS]) and FN/SFN (follicular neoplasm [FN] or suspicious for a follicular neoplasm [SFN], including Hürthle cell [oncocytic] type) have an estimated risk of malignancy of 10-40\% (5). Historically, these nodules commonly underwent repeat FNA and/or surgical removal. Approximately three-quarters of these were benign on surgical pathology, indicating the unnecessary surgical removal of many benign nodules. At the same time, malignant nodules potentially underwent inadequate initial treatment (6). Given the need for an improved means of predicting cancer risk and guiding surgical management in such nodules, novel diagnostic approaches have arisen, including the evaluation of genomic variants and fusions.

Initial studies included single genomic alterations, then small panels of several genes, and most recently numerous alterations among many genes (7-12). Despite discoveries of specific genetic variants and fusions in thyroid cancer specimens, many of these studies are not necessarily applicable to the preoperative evaluation of cytologically indeterminate thyroid nodules (ITNs) as they evaluated postsurgical histological rather than preoperative FNA specimens. Other studies only evaluated specific tumor histologies that are uncommon or differ strikingly from those seen among cytologically ITNs. Furthermore, it is often difficult to separate data specific to AUS/FLUS and FN/SFN nodules from those suspicious for malignancy (SFM), where the variant may have a different positive predictive value (PPV). For this reason, we examined the available published data on indi- vidual gene variants and fusions in preoperative cytologically indeterminate thyroid FNA samples from cohorts representative of routine clinical practice to determine their predictive values for thyroid malignancy.

\section{Review}

\section{Literature search}

To identify presurgical thyroid FNA specimens with AUS/ FLUS or SFN/FN cytology that underwent molecular testing and resection, we performed a PubMed search for studies published between January 1, 2009, and December 31, 2018 (see Supplementary Data S1 for the search keywords and search parameters). The resulting 540 abstracts were reviewed, and 113 publications that potentially met the inclusion criteria described below were combined with an additional 18 publications $(9,13-29)$ identified from bibliographies or personal files. These 131 publications underwent a detailed review and data extraction by at least 2 reviewers (Fig. 1). A second author independently repeated the original search and reviewed resulting abstracts identifying no additional publications that met our inclusion criteria.

\section{Inclusion/exclusion criteria}

The reviewed literature included both US and international studies, but three studies (39-41) written in languages other than English were excluded. Information on each study was extracted for the categories below to ensure the nodule and its corresponding data came from a representative cohort of tested patients (i.e., presurgical FNA of nodules with AUS/FLUS

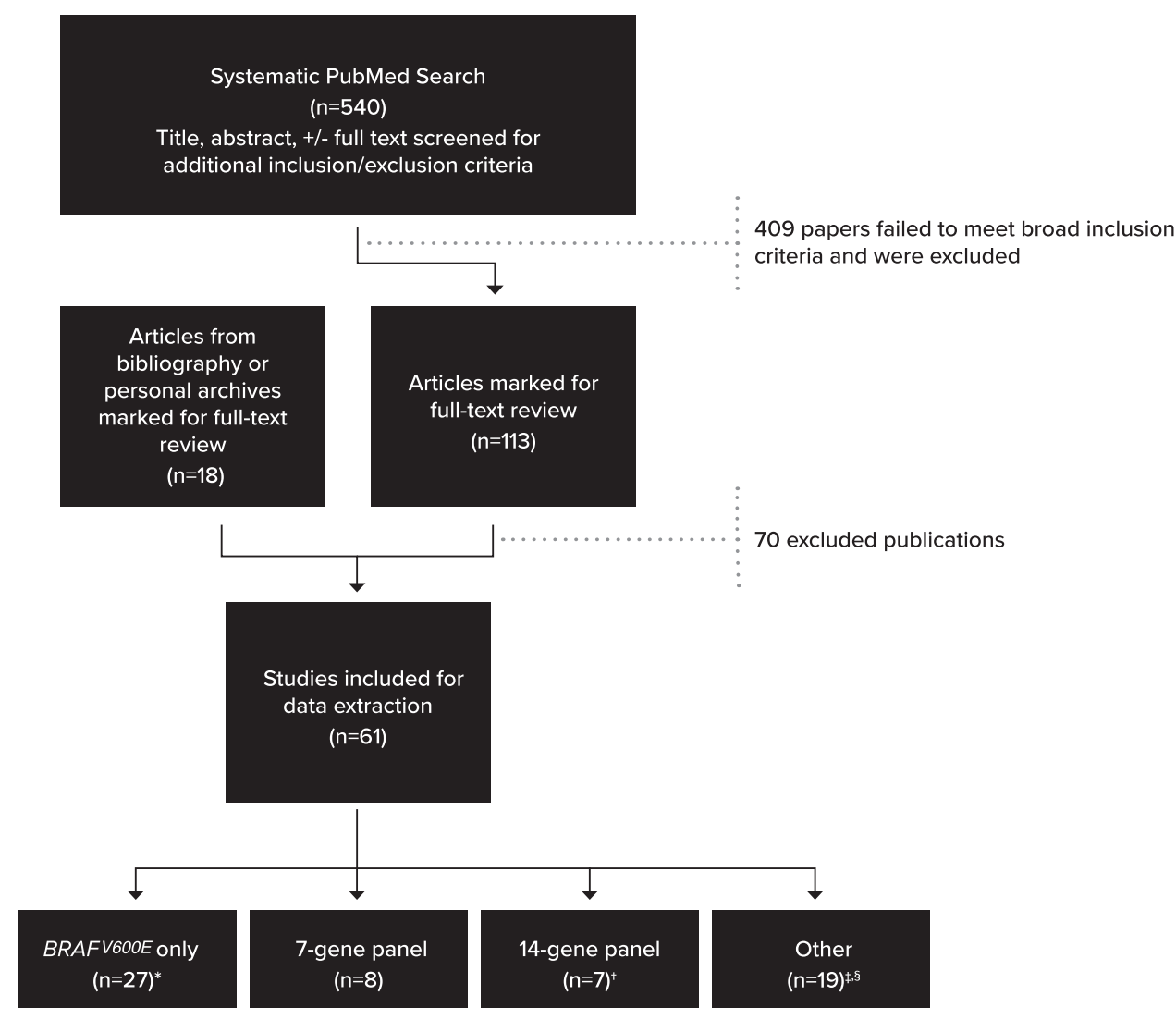

FIG. 1. Literature review flowchart. Breakdown of search results and study inclusion. See Supplementary Table S2 for details on exclusion. *One reflexed to $R A S$ if $B R A F$ was negative (no $R A S$ positives in indeterminate nodules) (30), while another only assessed $B R A F$ for variants and $R E T / P T C$ fusions (one RET/PTC1 was noted) (31). 'One study (32) combined data for patients run on either 7-gene or 14gene panel. "Nodules from certain publications (3336,38 ) were tested by 7 - or 14-gene panels but only reported data on a subset of genes, variants, and/or fusions. ${ }^{\S}$ One publication (37) analyzed nodules and reported data on two different panels. 
or SFN/FN cytology). Examples of nonrepresentative cohorts/ patients include: publications of unique patients, pediatric cases, or series that selectively included only some histopathologies (e.g., analysis limited to papillary thyroid cancer [PTC] nodules only). Full details of included and excluded publications are listed in Supplementary Tables S1 and S2, respectively.

- Presurgical sampling method:

- Studies included molecular testing performed on multiple types of presurgical samples: dedicated FNAs, needle washings, core biopsy, slide smears, or slide scrapings. Those with molecular results only performed on postsurgical tissue were excluded.

- Both prospective and retrospective studies were reviewed, but only studies pertaining to nodules with molecular testing and corresponding histological confirmation were included.

- Cytological category:

- ITNs, defined here as The Bethesda System for Reporting Thyroid Cytology: (AUS/FLUS and/or SFN/FN) or other cytological equivalents (Thy3a, Thy3f, TIR3a, TIR3b, etc.), were included.

- Cohorts referencing indeterminate cytology but not distinguishing between specific Bethesda categories had the possibility of including SFM samples. These studies were excluded unless data from the SFM samples could be separated from the molecular results of the other indeterminate specimens.

- Molecular techniques and gene inclusions:

- All molecular laboratory techniques were included, unless the authors specifically reported that the technique had a high potential for unreliable detection $(17,42,43)$. - The genes analyzed in each cohort, along with specific notation as to which genes and/or fusion pairs had positive results was recorded.

\section{Discrepancies and overlap}

Extracted data were compared by at least two reviewers per publication. Discrepancies were resolved by rereview, discussion, and the involvement of an additional reviewer if necessary. To avoid the potential of including nodule data more than once, studies published from the same institution were evaluated for potential cohort overlap. Studies with apparent overlap were identified, and the largest and/or latest study was included. Additionally, unless a review article separately analyzed a novel patient cohort (34), review articles were excluded to minimize potential for overlap. Some patient overlap may remain due to limited descriptions of cohorts within the respective studies.

\section{Data extraction and PPV calculation}

There was strong heterogeneity among the genes, variants, and fusions analyzed across the reviewed publications. The full list of variants and/or fusions assessed in most of the panels was not listed in the studies, so tracking of what was included in the panel was usually limited to the information provided for those nodules with genomic alterations. Information on any altered gene, along with the specific amino acid change, was collected when available. Data on the specific nucleotide change, however, were extremely limited, so all predictive data were analyzed at the level of the amino acid alteration for sequence variants. Both genes involved in a fusion pair were also documented, and samples with more than one variant and/or fusion in the same nodule were counted as positive for "multiple" variant status. When specific amino acid or fusion partner data were not available, the missing element was tracked as "unknown."

Variant data from each included publication were summarized by the total number with that variant and total true positives (TP) and false positives (FP). This permitted a risk of malignancy $[(\mathrm{TP} /(\mathrm{TP}+\mathrm{FP})]$ associated with that variant on a study-by-study level. All data from the same variant were then combined to create an overall variant risk of malignancy across all studies. Variants without the full designation were tallied separately at the gene, but unknown variant-level and similar study-specific and gene-specific risk of malignancies were generated. Significance of the difference between two independent proportions was calculated from the $z$-ratio and associated two-tailed probabilities (44).

\section{Study inclusion}

Sixty-one of the final 131 publications met the inclusion criteria (Fig. 1; Supplementary Table S1). This review included 4648 presurgical nodules having Bethesda AUS/FLUS and/or SFN/FN cytology with corresponding histological outcomes.

The main geographic origin of included studies was United States (38\%), Europe (29\%), and South Korea (26\%). Overall, $47 \%$ of publications analyzed only a single gene, most commonly those from South Korea (94\%) compared with those from Europe (50\%) or the United States (9\%). The only publications to report panels of $>7$ genes were from the United States (52\% of U.S. studies).

\section{Sampling}

Eighty-six percent ( $n=4021$ nodules) of studies analyzed data from dedicated FNA samples, whereas $12 \%$ analyzed samples $(n=566)$ from scrapings off cytology slides. Only one study (45), evaluating NRAS, used core biopsy to obtain samples $(n=61)$. Regardless of sampling method, $80 \%$ of studies had data from both indeterminate categories (i.e., AUS/FLUS and SFN/FN).

\section{Panels used}

Twenty-seven (44\%) studies focused exclusively on analysis of $B R A F^{V 600 E}$. Sixteen other different gene/fusion combinations were assessed across the remaining studies, including 8 analyzing a panel of 4 genes and 3 fusions (7gene panel), and 6 studies examining an expanded 14-gene panel. Although these 14-gene panels included the same genes assessed for sequence variants, the fusions analyzed varied and the full fusion set was not always listed. The remaining 20 studies looked at other combinations of genes/ fusions/panels ranging from 1 to 524 genes (Fig. 1; Supplementary Table S1; Supplementary Data S2). Some publications involving larger gene panels only reported data on a subset of genes/variants/fusions (e.g., tested samples by full 14-gene panel but only reported on TSHR findings) (33$36,38)$, limiting the interpretation of the full panel. 


\section{Cumulative molecular results}

Of the 4648 total nodules, 1187 (25.5\%) were positive for at least 1 variant or fusion, but half did not include the complete fusion pair and/or the specific amino acid change (Fig. 2). Of those with a known, specified single alteration, $94 \%$ were sequence variants and $6 \%$ were fusions. Taking together both known single sequence variants and fusions, overall PPV was $47 \%$ or $86 \%(p<0.0002)$ depending on whether $B R A F^{V 600 E}$ was removed or included, respectively. Twenty-two additional nodules from 10 studies had more than 1 variant. Table 1 details the various alterations reported.

\section{Sequence variants}

Only 12 genes had a variant identified, but of those reported as positive, $52 \%$ did not list the specific amino acid change (Fig. 2). BRAF ${ }^{V 600 E}$ was the most commonly analyzed variant (54 of 61 studies), with half of these publications assessing only for this variant. NRAS $S^{Q 61 R}, H R A S^{Q 61 R}$, and $B R A F^{K 601 E}$ were the only other specified sequence changes to be found in more than 10 nodules each. These sequence-change variants, along with $B R A F^{V 600 E}$, made up $76 \%$ of the total known sequence variant positive nodules in multi-gene analyses. Twenty-six additional variants across 8 genes were noted in 50 nodules.

For all variants with known sequence changes, the overall PPV was $87 \%$ (individual variant PPV ranged from $0 \%$ to $100 \%) . B R A F^{V 600 E}, N R A S^{Q 61 R}, H R A S^{Q 61 R}$, and BRAF $F^{K 601 E}$ accounted for $95 \%$ of all TP and have a combined PPV of $91 \%$, but the high PPV is primarily driven by $B R A F^{V 600 E}$. When $B R A F^{V 600 E}$ is removed, the cumulative PPV of the remaining 3 variants was lowered significantly to $40 \%(p<0.0002)$.

BRAF $\mathrm{V} 600 \mathrm{E}$. Fifty-four of 61 studies assessed samples for $B R A F^{V 600 E}, 9$ of which did not have any nodules positive for this variant (Supplementary Fig. S1). In these 54 publications, 430 of 4293 nodules $(10 \%)$ were V600E positive. Histology was malignant in 422, corresponding to a PPV of 98\% (95\% confidence interval [CI 96-99\%]).
$B R A F^{V 601 E}$. The K601E variant for $B R A F$ was the third most reported known variant with 12 nodules reported across 8 studies. Five TP were reported across 4 studies, yielding a PPV of $42 \%$ [CI 19-68\%].

RAS. RAS genes were assessed in some manner in $94 \%$ of publications that analyzed more than just $B R A F^{V 600 E}$. Across these 33 publications, 607 of 2674 nodules $(23 \%)$ contained a $R A S$ variant with a corresponding $66 \%$ PPV [CI 63-70\%]. However, $R A S$ gene and/or variant specification was missing from 541 (89\%) of these nodules (Figs. 2 and 3). When considering only the remaining 66 nodules from 8 studies, the PPV was reduced to 44\% ([CI 33-56\%], $p=0.0003$ ). When the specific $R A S$ gene was provided, NRAS was 1.8 times more likely to be altered than the other 2 genes combined ( $n=335$ vs. $123 H R A S+66 K R A S)$. The genespecific data showed differing PPV across $R A S$ genes when variants were specified (HRAS 63\%, NRAS 38\%, KRAS 25\%) versus when unknown variants were also included (HRAS 74\%, NRAS 65\%, KRAS 51\%).

$N R A S^{Q 61 R}$ was the most reported $R A S$ variant and had malignant histology in 12 of 32 nodules (PPV $=37.5 \%$ [CI 23-55\%]). It was the second most reported specific variant after $B R A F^{V 600 E}$, but with significantly lower PPV $(p<0.0002)$. The fourth most reported variant was also in the $R A S$ family, $H R A S^{Q 61 R}$. It was present in 11 nodules across 6 studies with a PPV of $45 \%$ [CI 22-72\%].

TERT promoter. Fifteen studies (25\%) assessed for TERT promoter (TERTp) (C228T and C250T) variants. Overall, $1.6 \%$ of nodules in these studies contained a specified TERTp variant, either as a solitary variant $(43 \%)$ or as a part of a multiple variant $(57 \%)$. Solitary TERTp variants were found in 9 nodules across 5 publications with a PPV of $88 \%$ [CI 56-98\%], although the specific TERTp was not always specified. When the specific promoter variant was noted ( 7 of 9 cases), C228T was more frequently reported than $\mathrm{C} 250 \mathrm{~T}$ (6 nodules and 1 nodule, respectively).

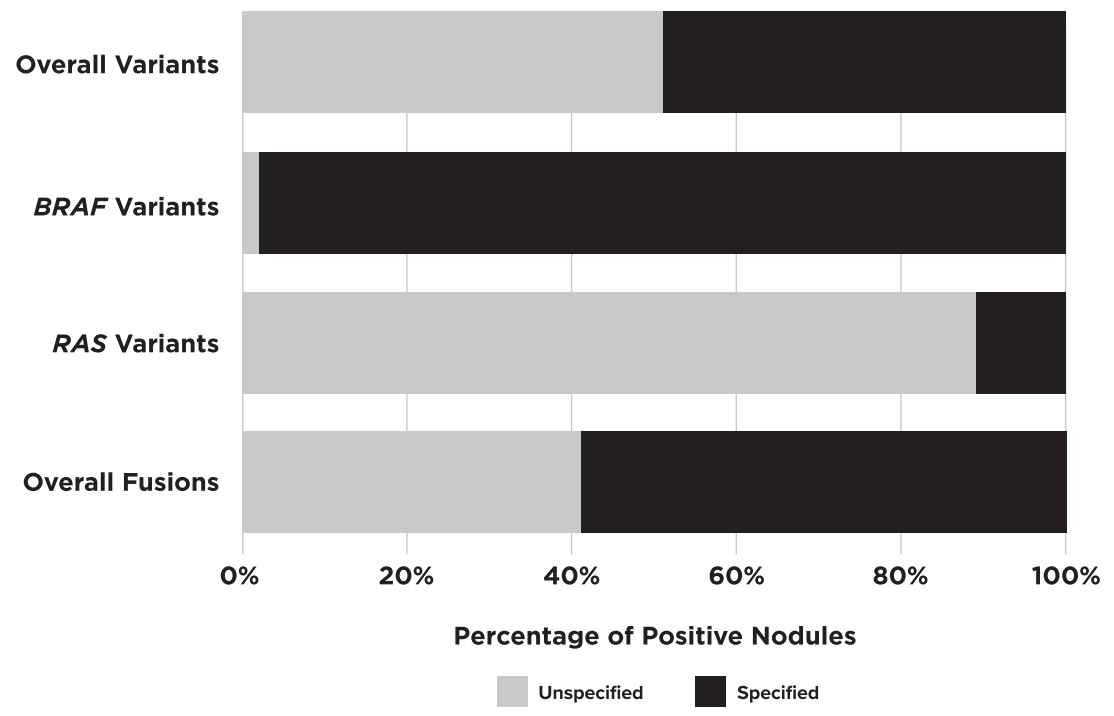

FIG. 2. Specified breakdown of variants/fusions. Percentage of positive nodules identified with unspecified amino acid changes or incomplete fusions pairs versus those that had them specified. $H-/ K-/ N-R A S$ data are significantly lower for specified variant designation than $B R A F(p<0.0001)$ when looking at these data for sequence variants alone. 
Table 1. Reported Variants and Fusions

\begin{tabular}{|c|c|c|c|c|}
\hline Gene & $\begin{array}{l}\text { Amino acid } \\
\text { change }\end{array}$ & $\begin{array}{l}\text { TP/total } \\
\text { positives }\end{array}$ & $P P V$ & References \\
\hline \multicolumn{5}{|l|}{ Sequence variants } \\
\hline$B R A F$ & V600_K601>E & $1 / 1$ & & $(46)$ \\
\hline$B R A F$ & V600E & $422 / 430$ & $98.1 \%$ & $\begin{array}{l}(16,18,20,22,24,25,28,30-32,46, \\
49-53,55,56,59,61,62,64,66-88)\end{array}$ \\
\hline$B R A F$ & Unknown & $9 / 9$ & - & $(32,37,47,48)$ \\
\hline BRAF & K601E & $5 / 12$ & $41.7 \%$ & $(46,49-55)$ \\
\hline EIF1AX & A113 splice & $0 / 4$ & & $(53)$ \\
\hline EIF $1 A X$ & Unknown & $3 / 9$ & - & $(32,37,48,49,55)$ \\
\hline FAT1 & V912I & $0 / 1$ & & (9) \\
\hline$H R A S$ & Unknown & 79/104 & - & $(34,35,37,46-51,55,56)$ \\
\hline HRAS & G12V & $1 / 2$ & & (33) \\
\hline$H R A S$ & Q61H & $1 / 1$ & & (57) \\
\hline$H R A S$ & Q61K & $3 / 3$ & & $(55,57)$ \\
\hline$H R A S$ & Q61P & $2 / 2$ & & $(57)$ \\
\hline HRAS & Q61R & $5 / 11$ & $45.4 \%$ & $(33,53,55,57-59)$ \\
\hline$K R A S$ & Unknown & $32 / 58$ & - & $(34,35,37,46,47,49-51,55,56,60)$ \\
\hline KRAS & G12C & $0 / 2$ & & $(55,61)$ \\
\hline$K R A S$ & G12D & $0 / 2$ & & $(55)$ \\
\hline$K R A S$ & G12V & $0 / 2$ & & $(55,59)$ \\
\hline$K R A S$ & Q61R & $2 / 2$ & & $(59,61)$ \\
\hline$M E T^{\mathrm{a}}$ & Unknown & $3 / 4$ & & $(37,56)$ \\
\hline NRAS & Unknown & $202 / 296$ & - & $(34,35,37,45-52,55,56,60-63)$ \\
\hline NRAS & Q61K & $3 / 7$ & & $(57-59,61,64)$ \\
\hline NRAS & Q61R & $12 / 32$ & $37.5 \%$ & $(33,53,57-59,61)$ \\
\hline PTEN & Unknown & $0 / 2$ & - & $(49,63)$ \\
\hline$R A S$ (not otherwise specified) & Unknown & $61 / 83$ & - & $(65-70)$ \\
\hline$R E T$ & Unknown & $1 / 1$ & - & (32) \\
\hline TERT & Unknown promoter & $1 / 2^{\mathrm{b}}$ & - & (48) \\
\hline TERT & $\mathrm{C} 250 \mathrm{~T}$ & $1 / 1$ & & (46) \\
\hline TERT & $\mathrm{C} 228 \mathrm{~T}$ & $6 / 6$ & & $(46,50,54,69)$ \\
\hline TP53 & Unknown & $0 / 1$ & - & (32) \\
\hline TSHR & I630L & $1 / 1$ & & (38) \\
\hline TSHR & D633H & $0 / 1$ & & (38) \\
\hline$T S H R$ & $\mathrm{I} 486 \mathrm{~F}$ & $0 / 1$ & & (38) \\
\hline TSHR & T632A & $0 / 1$ & & (38) \\
\hline TSHR & P631L & $0 / 1$ & & (38) \\
\hline TSHR & $\mathrm{I} 586 \mathrm{~F}$ & $0 / 1$ & & (38) \\
\hline TSHR & L512Q & $0 / 1$ & & (38) \\
\hline TSHR & L512R & $0 / 1$ & & (38) \\
\hline TSHR & M453T & $0 / 3$ & & $(9,36)$ \\
\hline TSHR & D633E & $0 / 1$ & & $(38)$ \\
\hline TSHR & $\mathrm{I} 486 \mathrm{M}$ & $0 / 1$ & & (36) \\
\hline TSHR & I568T & $0 / 1$ & & (36) \\
\hline TSHR & Unknown & $1 / 7$ & - & $(37,48,50,55)$ \\
\hline \multicolumn{5}{|l|}{ Fusion pairs } \\
\hline SND1_BRAF & $\mathrm{n} / \mathrm{a}$ & $0 / 1$ & & (9) \\
\hline ETV6_NTRK3 & $\mathrm{n} / \mathrm{a}$ & $1 / 1$ & & $(53)$ \\
\hline PAX8_PPARG & $\mathbf{n} / \mathbf{a}$ & $11 / 20$ & $\mathbf{5 5 . 0 \%}$ & $(9,32,47,48,53,55,56,58,65,67,68)$ \\
\hline$R E T \_\bar{P} T C 1$ & $\mathrm{n} / \mathrm{a}$ & $3 / 3$ & & $(31,53,62)$ \\
\hline RET_PTC3 & $\mathrm{n} / \mathrm{a}$ & $2 / 2$ & & $(47)$ \\
\hline$R E T_{-} P T C$ (unknown) & $\mathrm{n} / \mathrm{a}$ & $2 / 2$ & - & $(66,67)$ \\
\hline THADA_IGF2BP3 & $\mathrm{n} / \mathrm{a}$ & $5 / 5$ & & $(48,53,55)$ \\
\hline THADA_(unknown) & $\mathrm{n} / \mathrm{a}$ & $8 / 9$ & - & $(49,50,63)$ \\
\hline (unknown)_ALK & $\mathrm{n} / \mathrm{a}$ & $1 / 1$ & - & (49) \\
\hline (unknown)_NTRKI & $\mathrm{n} / \mathrm{a}$ & $1 / 1$ & - & (49) \\
\hline (unknown)_NTRK3 & $\mathrm{n} / \mathrm{a}$ & $3 / 3$ & - & $(49,50)$ \\
\hline (unknown)_PPARG & $\mathrm{n} / \mathrm{a}$ & $5 / 6$ & - & $(37,49,50)$ \\
\hline \multicolumn{5}{|l|}{ Multiple mutations } \\
\hline TP53 (T221I) and TP53 (Q331X) & & $0 / 1$ & & (53) \\
\hline EIFIAX and TSHR & & $0 / 1$ & & (55) \\
\hline$H R A S$ and $R E T$ & & $0 / 1$ & & (32) \\
\hline
\end{tabular}


TABle 1. (CONTINUEd)

\begin{tabular}{|c|c|c|c|c|}
\hline Gene & $\begin{array}{c}\text { Amino acid } \\
\text { change }\end{array}$ & $\begin{array}{l}\text { TP/total } \\
\text { positives }\end{array}$ & $P P V$ & References \\
\hline NRAS (Q61R) and RET/PTC1 & & $1 / 1$ & & (55) \\
\hline$N R A S$ and TSHR & & $1 / 1$ & & (32) \\
\hline$N R A S$ and $P I K 3 C A$ and TP53 & & $1 / 1$ & & $(50)$ \\
\hline$T E R T(\mathrm{C} 250 \mathrm{~T})$ and $B R A F(\mathrm{~K} 601 \mathrm{E})$ & & $1 / 1$ & & (46) \\
\hline TERT (C228T) and BRAF (K601E) & & $1 / 1$ & & (54) \\
\hline TERT (C228T) and KRAS (codon 12) & & $1 / 1$ & & (46) \\
\hline TERT (C228T) and NRAS (codon 61) & & $3 / 3$ & & (46) \\
\hline$T E R T(\mathrm{C} 228 \mathrm{~T})$ and $N R A S$ & & $2 / 2$ & & $(50)$ \\
\hline TERT and EIF1AX and NRAS (Q61K) & & $1 / 1$ & & (55) \\
\hline$T E R T$ and $B R A F$ and $A K T I$ and $P I K 3 C A$ & & $1 / 1$ & & (32) \\
\hline$N R A S$ and $T S H R$ and $T E R T$ & & $1 / 1$ & & (63) \\
\hline$N R A S$ and $T E R T$ & & $1 / 1$ & & (63) \\
\hline HRAS and EIFIAX & & $1 / 2$ & & $(37,63)$ \\
\hline$N R A S$ and TP53 & & $1 / 1$ & & (56) \\
\hline GNAS $(Q 227 H)$ and EIF1AX $(R 13 P)$ & & $0 / 1$ & & (36) \\
\hline
\end{tabular}

List of all reported sequence variants and fusions (whether amino acid change is specified or unspecified) and the corresponding PPV and publications. Bold entries were present with amino acid change in $\geq 10$ nodules, which was our threshold for reporting PPV or TP over total positives. Only 5 of 36 reported variants were reported with this frequency.

${ }^{\text {a}}$ Although one study (37) specifically referred to mutation in $M E T$, panel did not mention $M E T$ as a gene being analyzed for variants. The other study (56) did not say how MET was affected, only that it was positive.

${ }^{\mathrm{b}}$ The TP in this group was noted as a TERT promoter variant, but no specific amino acid change was listed.

n/a, not applicable; PPV, positive predictive value; TP, true positive.

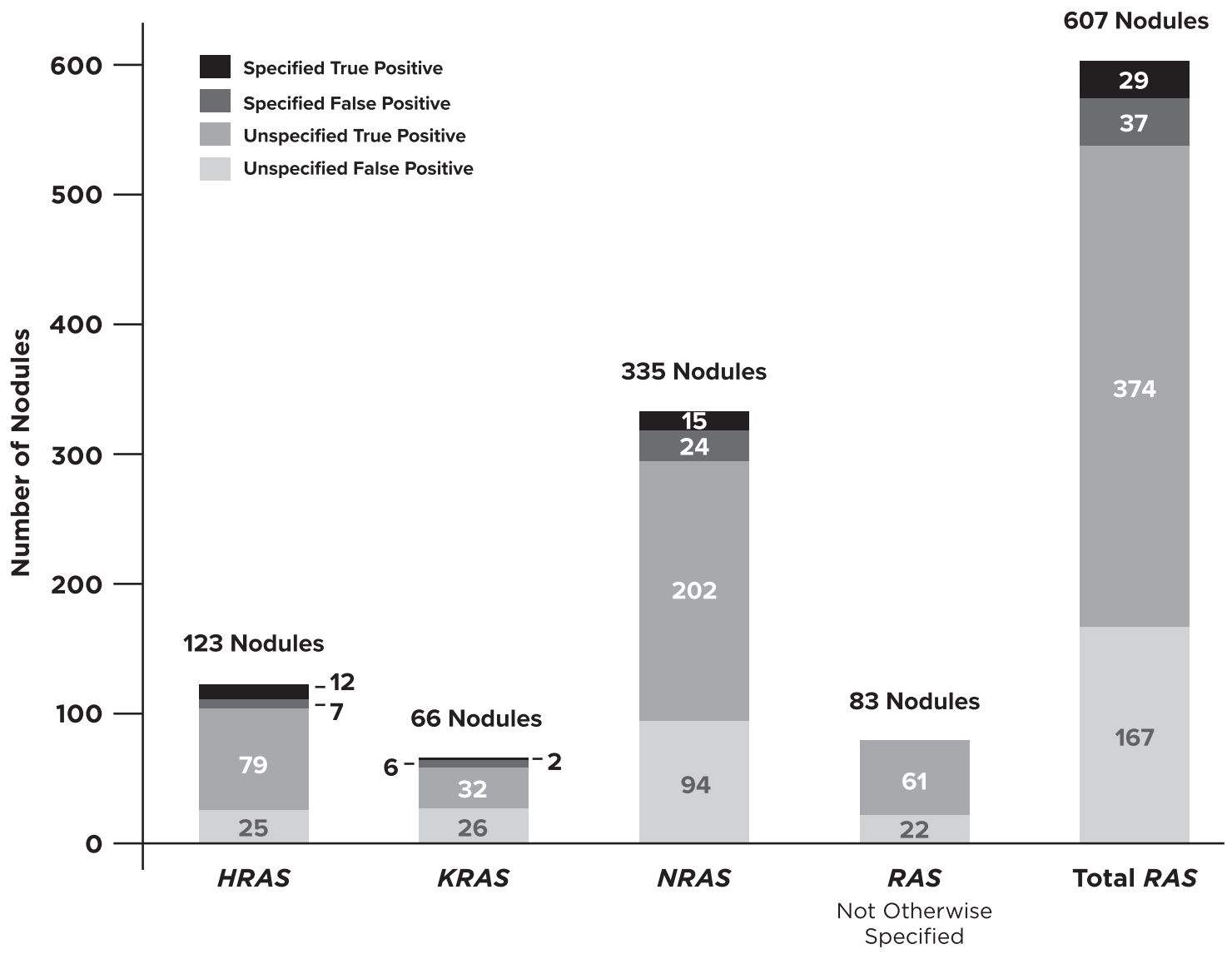

FIG. 3. RAS data breakdown. Ratios of specified versus unspecified amino acid changes separated by data for all $R A S$ positive nodules, data for $R A S$ without the gene specified, and data for $H-/ K-/ N-R A S$ along with the corresponding breakdown of true and false positives. This figure shows that specified data were very minimal for this gene category (66/607 $R A S$-positive nodules). 


\section{Fusions}

Fusions were reported in 22 of the 61 studies (36\%). Fiftyfour nodules had fusions involving 13 genes with both known $(59 \%)$ and unknown $(41 \%)$ partners (i.e., not listing both partners in the fusion pair) (Fig. 2). Among studies that assessed fusions, $3 \%$ of nodules were positive for a single fusion; however, the total positives for any completely specified fusions were usually too small $(n<10)$ to confidently estimate a PPV point value. Overall, the PPV for fusions was $69 \%$ or $78 \%$ depending on whether both partners were or were not specified, respectively (range $0-100 \%, p=0.3539$ ).

PAX8/PPARG. Twenty nodules across 11 studies carried this fusion pair and accounted for $37 \%$ of all reported fusions and $63 \%$ of fusions in which both fusion partners are known. This fusion demonstrated a PPV of 55\% [CI 34-78\%]. An additional 6 nodules from 3 studies were noted as having a PPARG fusion $(\mathrm{PPV}=83 \%)$, but the gene partner was not listed.

RET/PTC. Only 7 RET/PTC fusions were identified, 3 RET/PTC1, 2 RET/PTC3, and 2 with an unreported PTC partner, comprising $13 \%$ of all fusions. It was the second most noted fusion pair, although with a higher PPV of $100 \%$ [CI 57-100\%].

THADA fusions. The THADA/IGF $2 B P 3$ fusion was the third most reported fusion, reported 5 times across 3 studies with a cumulative PPV of $100 \%$ [CI 57-100\%]. Nine additional nodules having THADA fusions without listing the corresponding fusion partner were noted in 3 publications, 1 being FP.

\section{Multiple variants in one nodule}

Ten studies (approximately one-third of studies analyzing $\geq 1$ gene) reported finding multiple variants in the same nodule with corresponding histological confirmation. Overall nodules with multiple variants comprised $<1 \%$ of all nodules across these cohorts. Sixteen different combinations were seen with a cumulative PPV of 77\% [CI 57-90\%]. The various combinations, ranging from 2 different sequence variants in 1 gene to 4 variants in 4 separate genes, are listed in Table 1. Most combinations were unique or missing detailed nomenclature, making reliable point estimates of PPV for each combination difficult.

\section{Discussion}

We evaluated the incidence and PPV of genetic variants and fusions on preoperative clinical specimens from $>4600$ thyroid nodules with indeterminate cytology from 61 publications. Our analysis was restricted to cohorts representative of general clinical practice (i.e., those with preoperative collection, indeterminate cytopathology, histological confirmation) so that we could understand the PPV of these genetic changes in similar cohorts.

Overall, $26 \%$ of nodules were positive for at least one variant and/or fusion. Sequence-changing variants made up the majority (94\%) of aberrations found. However, approximately half of these cases only had information on genes involved and not the specific amino acid or resultant protein change, hence only a gene-level PPV could be calculated. This is important because it is likely that variants in the same gene are associated with different PPVs. This was particularly common within the $R A S$ gene family ( $H R A S, K R A S$, and $N R A S)$. Unlike the $98 \%$ proper designation for $B R A F$ variants, nodules positive for $R A S$ variants were missing the specific gene or variant designation in $14 \%$ and $75 \%$ of cases, respectively (Fig. 3). Similarly, missing fusion partners limited our ability to reliably estimate predictive values for many specific fusion pairs.

American Thyroid Association (ATA) guidelines identify $B R A F^{V 600 E}, R E T / P T C$, and PAX8/PPARG as having high enough PPV ( $>95 \%)$ to be considered "rule-in" tests. Our data show a similarly high PPV for $B R A F^{V 600 E}(98 \%)$ and combined RET/PTC fusions (100\%), but a much lower PPV (55\%) for $P A X 8 / P P A R G$ fusions. The small individual sample size of the remaining reported variants in the literature creates PPVS with wide CIs. Outside $B R A F^{V 600 E}$, the likelihood of cancer for those variants documented as positive in at least 10 nodules in the included studies $\left(B R A F^{K O 1 E}, H R A S^{q 61 R}, N R A S^{q 61 R}\right.$, and $P A X 8 / P P A R G$ fusion) ranged from $37 \%$ to $55 \%$. Multiple variants in the same nodule were rare, with an incidence of $<1 \%$ in studies that assessed more than one gene and yielded a cumulative PPV of $77 \%$. Although these risks are increased above the a priori cytological risk, these values are not high enough to consider these as "rule-in" results for thyroid carcinoma [i.e., $\geq 98.6 \%$ per ATA guidelines (3)].

\section{Importance of adequate sample size}

Despite some panels having up to 524 genes, only 26 genes harbored a variant or fusion (Table 1), reflective of the low frequency of somatic variants observed in thyroid cancer surgical tissues compared with other cancers $(7,89)$. Thirty-six separate sequence variants or fusions were noted, yet $44 \%$ were reported only once. Only $14 \%$ of specific variants or fusions $(n=5)$ were seen in $\geq 10$ nodules with associated surgical histopathology. Without adequate sample sizes, confident point estimate calculations of PPV are not possible. An estimated sample size of close to 100 nodules affected with any given variant is needed to achieve a CI of $\pm 10 \%$ allowing for more confident PPV estimates. Only $B R A F^{V 600 E}$ has been reported frequently enough among ITNs to meet this qualification. If the specific variant data had been documented for all $R A S$-positive nodules, better estimates of their true PPV may have been possible.

\section{Importance of assessing PPV by individual variant}

An overall PPV of $68 \%$ was seen for all single variants/ fusions positive by multi-gene panels. As in other cell types, thyroid nodules harbor a variety of genomic aberrations that have varying levels of association with cancer. Due to its markedly high specificity compared with most other variants, the frequency of $B R A F^{V 600 E}$ within a cohort could significantly affect the apparent cumulative PPV of the panel. Indeed, removing $B R A F^{V 600 E}$ data from the multiple panel studies reduced the overall remaining PPV to $49 \%(p=0.0002)$.

It is well accepted that $B R A F^{V 600 E}$ has a much higher PPV than K601E, but corollary differences are less recognized for $R A S$ and other variants. The data presented here suggest that 
variants in $K R A S$ have a significantly lower PPV than variants in NRAS ( $p=0.002)$, and as more variant-specific PPV data on $R A S$ become available, this may also hold true at the variant level. Differing cancer risks among specific variants may contribute to the heterogeneity reported for $R A S$ performance across different studies $(90,91)$. Thus, assigning a risk interpretation to a panel or group of genes/variants rather than to individual specific variants may be less accurate. We also believe that it is likely that understanding tumor prediction and prognostics at the specific variant level will increase personalized prediction accuracy and treatment decisions (92).

\section{Limitations}

Our goal was to include all relevant publications. There are known limitations for online searches, so we extended our search to include bibliographies of articles identified by the online search and personal libraries known to include articles relevant to this topic. To ensure the additional off-line search methods did not skew the results, data were reanalyzed using only the publications found via the online search and yielded no significant differences.

Additionally, the panel heterogeneity limited the ability to directly compare results of any two publications and estimate accurate incidences. This heterogeneity, along with data only available on operated positive cases in most studies, also made calculations of sensitivity unreliable.

Another potential limitation is that our analysis utilized local, largely unblinded histological diagnoses, as opposed to a blinded panel of expert histopathologists. Caution should be exercised in generalizing any single center's experience to other populations. Imperfect diagnostic concordance among pathologists is known, especially among follicular and oncocytic lesions, and tendencies to categorize such lesions as benign or malignant along with the unblinded nature of such diagnoses could impact locally derived PPVs and would generate heterogeneity among PPV estimates between institutions with differing tendencies (91).

We were concerned about generalizing PPV estimates on variants with lower specificities across multiple cytological categories having a wide variation in malignancy prevalence. There is a more similar pretest risk of malignancy across the AUS/FLUS and FN/SFN categories that do not extend to the SFM group. ATA guideline recommendations $17 \mathrm{a}$ and 20 suggest that SFM nodules be treated as if they were cytologically malignant nodules (3). The higher pretest risk of malignancy and the predominance of PTCs in higher categories would markedly influence a variant's PPV. It is for these reasons that our protocol and search terms were designed to capture data on AUS/FLUS and FN/SFN only. Future investigation into predictive values and clinical utility of these variants across other Bethesda cytological categories may be warranted.

Finally, our study is unable to fully quantify the impact of the noninvasive follicular thyroid neoplasms with papillarylike nuclear features (NIFTP) histological category upon PPV calculations. NIFTP are considered to have a low risk of malignant behavior following surgical excision and are considered as a cancer in situ. Most publications included in our study accrued patients before the formal recognition of NIFTP, and these neoplasms would have been labeled follicular variant of PTCs and considered malignant. Of the publications in our analysis that reported NIFTP histology in their results $(22,27,37,46,48,53,54,63,69)$, we considered them as "malignant" for statistical purposes, consistent with the current desire that they undergo surgical resection as opposed to in situ observation. Thus, PPVs in our study estimate the combined probably of cancer or NIFTP. However, if NIFTP cases were to be included with the benign diagnoses, PPVs of variants found in these samples would be further lowered, particularly THADA/IGF2BP3 fusions, which would be reduced from $100 \%$ to $20 \%$.

\section{Reporting variants in future studies}

Future studies with complete data could provide data to allow for (i) incidence and PPV refinement by variant and/or cytology subcategory, (ii) better correlation of certain variants to neoplastic and oncogenic subtypes (e.g., NIFTP) allowing for a more detailed risk prediction, and (iii) investigation of the independent contribution of the genomic profile to prognosis. We suggest a data chart (Supplementary Table S3) to standardize reporting in future studies.

While our study highlights the limited data available on the association of most variants and fusions to predict cancer among cytologically ITNs, data are beginning to emerge linking genomic alterations with specific types of neoplasms, their behavior, routes of metastasis, and prognosis (7-9). Data to support the independent prognostic value of genomics are currently sparse, however, and randomized controlled studies based on the presence of a specific variant have not been performed to demonstrate clinical utility for a variant-based treatment plan.

\section{Conclusions}

Evaluation for genomic variants or fusions in DNA and/or RNA from thyroid nodule FNAs has been increasingly used to predict risks of malignancy in cytologically ITNs. However, only a few alterations $\left(B R A F^{V 600 E}, B R A F^{K 601 E}, N R A S^{Q 61 R}\right.$, $H R A S^{Q 61 R}$, and PAX8/PPARG) have been reported in sufficient numbers from representative cohorts with histological confirmation to estimate meaningful predictive values. In this review, genomic alterations were present in a quarter of cytologically ITNs with $B R A F^{V 600 E}$ as the most common. However, RAS gene variants were the second most common, but data on specific variants in these and other genes were commonly not specified, making it impossible to determine accurate individual variant/fusion predictive values.

Furthermore, gene- or panel-level PPV, rather than individual variant or fusion-level PPV, may over- or underestimate the overall risk. To best estimate the true predictive and prognostic value of a specific genetic alteration, the cytological category, genomic and histological details for each individual variant/fusion from a cohort representative of those encountered in clinical practice need to be documented in a standard manner. The importance of accurate genomic variant designation will only continue to grow with the further advancements of precision medicine therapies.

\section{Author Disclosure Statement}

J.B., R.T.K., and S.L.M. are employees of Veracyte, Inc. which offers a molecular test for indeterminate thyroid 
nodules. P.M.S. is consultant for Veracyte, Inc. T.E.A., F.A.N., C.N., and W.S.G. have no competing financial interests.

\section{Funding Information}

No funding was received for this article.

\section{Supplementary Material}

Supplementary Figure S1

Supplementary Data S1

Supplementary Data S2

Supplementary Table S1

Supplementary Table S2

Supplementary Table S3

\section{References}

1. Grani G, Lamartina L, Ascoli V, Bosco D, Biffoni M, Giacomelli L, Maranghi M, Falcone R, Ramundo V, Cantisani V, Filetti S, Durante C 2019 Reducing the number of unnecessary thyroid biopsies while improving diagnostic accuracy: toward the "right" TIRADS. J Clin Endocrinol Metab 104:95-102.

2. Cavallo A, Johnson DN, White MG, Siddiqui S, Antic T, Mathew M, Grogan RH, Angelos P, Kaplan EL, Cipriani NA 2017 Thyroid nodule size at ultrasound as a predictor of malignancy and final pathologic size. Thyroid 27:641-650.

3. Haugen BR, Alexander EK, Bible KC, Doherty GM, Mandel SJ, Nikiforov YE, Pacini F, Randolph GW, Sawka AM, Schlumberger M, Schuff KG, Sherman SI, Sosa JA, Steward DL, Tuttle RM, Wartofsky L 20162015 American Thyroid Association Management Guidelines for Adult Patients with Thyroid Nodules and Differentiated Thyroid Cancer: The American Thyroid Association Guidelines Task Force on Thyroid Nodules and Differentiated Thyroid Cancer. Thyroid 26:1-133.

4. Grant EG, Tessler FN, Hoang JK, Langer JE, Beland MD, Berland LL, Cronan JJ, Desser TS, Frates MC, Hamper UM, Middleton WD, Reading CC, Scoutt LM, Stavros AT, Teefey SA 2015 Thyroid Ultrasound Reporting Lexicon: White Paper of the ACR Thyroid Imaging, Reporting and Data System (TIRADS) Committee. J Am Coll Radiol 12: 1272-1279.

5. Cibas ES, Ali SZ 2017 The 2017 Bethesda System for Reporting Thyroid Cytopathology. Thyroid 27:1341-1346.

6. Schneider DF, Cherney Stafford LM, Brys N, Greenberg CC, Balentine CJ, Elfenbein DM, Pitt SC 2017 Gauging the extent of thyroidectomy for indeterminate thyroid nodules: an oncologic perspective. Endocr Pract 23:442-450.

7. Cancer Genome Atlas Research Network 2014 Integrated genomic characterization of papillary thyroid carcinoma. Cell 159:676-690.

8. Yoo SK, Lee S, Kim SJ, Jee HG, Kim BA, Cho H, Song YS, Cho SW, Won JK, Shin JY, Park do J, Kim JI, Lee KE, Park YJ, Seo JS 2016 Comprehensive analysis of the transcriptional and mutational landscape of follicular and papillary thyroid cancers. PLoS Genet 12:e1006239.

9. Pagan M, Kloos RT, Lin CF, Travers KJ, Matsuzaki H, Tom EY, Kim SY, Wong MG, Stewart AC, Huang J, Walsh PS, Monroe RJ, Kennedy GC 2016 The diagnostic application of RNA sequencing in patients with thyroid cancer: an analysis of 851 variants and 133 fusions in 524 genes. BMC Bioinformatics 17(Suppl. 1):6.

10. Pozdeyev N, Gay LM, Sokol ES, Hartmaier R, Deaver KE, Davis S, French JD, Borre PV, LaBarbera DV, Tan AC,
Schweppe RE, Fishbein L, Ross JS, Haugen BR, Bowles DW 2018 Genetic analysis of 779 advanced differentiated and anaplastic thyroid cancers. Clin Cancer Res 24:30593068.

11. Ye L, Zhou X, Huang F, Wang W, Qi Y, Xu H, Yang S, Shen L, Fei X, Xie J, Cao M, Zhou Y, Zhu W, Wang S, Ning G, Wang W 2017 The genetic landscape of benign thyroid nodules revealed by whole exome and transcriptome sequencing. Nat Commun 8:15533.

12. Jung SH, Kim MS, Jung CK, Park HC, Kim SY, Liu J, Bae JS, Lee SH, Kim TM, Lee SH, Chung YJ 2016 Mutational burdens and evolutionary ages of thyroid follicular adenoma are comparable to those of follicular carcinoma. Oncotarget 7:69638-69648.

13. Elsayed YA, El-Latif AMA, Zaghloul MHE, Lofty SE, Mahmoud MM 2018 Diagnostic and prognostic utility of NRAS mutation gene testing in cytologically indeterminate thyroid nodules. Int J Adv Res 6:744-753.

14. Armstrong MJ, Yang H, Yip L, Ohori NP, McCoy KL, Stang MT, Hodak SP, Nikiforova MN, Carty SE, Nikiforov YE 2014 PAX8/PPARgamma rearrangement in thyroid nodules predicts follicular-pattern carcinomas, in particular the encapsulated follicular variant of papillary carcinoma. Thyroid 24:1369-1374.

15. Girlando S, Cuorvo LV, Bonzanini M, Morelli L, Amadori P, Dalla Palma P, Barbareschi M 2010 High prevalence of B-RAF mutation in papillary carcinoma of the thyroid in north-east Italy. Int J Surg Pathol 18:173-176.

16. Kim SK, Hwang TS, Yoo YB, Han HS, Kim DL, Song KH, Lim SD, Kim WS, Paik NS 2011 Surgical results of thyroid nodules according to a management guideline based on the BRAF(V600E) mutation status. J Clin Endocrinol Metab 96:658-664.

17. Kim SW, Lee JI, Kim JW, Ki CS, Oh YL, Choi YL, Shin JH, Kim HK, Jang HW, Chung JH 2010 BRAF $^{\mathrm{V} 600 \mathrm{E}} \mathrm{mu}-$ tation analysis in fine-needle aspiration cytology specimens for evaluation of thyroid nodule: a large series in a $\mathrm{BRAF}^{\mathrm{V} 600 \mathrm{E}}$-prevalent population. J Clin Endocrinol Metab 95:3693-3700.

18. Koh J, Choi JR, Han KH, Kim EK, Yoon JH, Moon HJ, Kwak JY 2013 Proper indication of BRAF(V600E) mutation testing in fine-needle aspirates of thyroid nodules. PLoS One 8:e64505.

19. Nikiforova MN, Wald AI, Roy S, Durso MB, Nikiforov YE 2013 Targeted next-generation sequencing panel (ThyroSeq) for detection of mutations in thyroid cancer. J Clin Endocrinol Metab 98:E1852-E1860.

20. Park KS, Oh YL, Ki CS, Kim JW 2015 Evaluation of the real-Q BRAF V600E detection assay in fine-needle aspiration samples of thyroid nodules. J Mol Diagn 17:431-437.

21. Patel A, Klubo-Gwiezdzinska J, Hoperia V, Larin A, Jensen K, Bauer A, Vasko V 2011 BRAF(V600E) mutation analysis from May-Grunwald Giemsa-stained cytological samples as an adjunct in identification of high-risk papillary thyroid carcinoma. Endocr Pathol 22:195-199.

22. Rossi ED, Martini M, Capodimonti S, Cenci T, Bilotta M, Pierconti F, Pontecorvi A, Lombardi CP, Fadda G, Larocca LM 2018 Morphology combined with ancillary techniques: an algorithm approach for thyroid nodules. Cytopathology 29:418-427.

23. Rossi M, Buratto M, Bruni S, Filieri C, Tagliati F, Trasforini G, Rossi R, Beccati MD, Degli Uberti EC, Zatelli MC 2012 Role of ultrasonographic/clinical profile, cytology, and BRAF V600E mutation evaluation in thyroid 
nodule screening for malignancy: a prospective study. J Clin Endocrinol Metab 97:2354-2361.

24. Seo JY, Kim EK, Baek JH, Shin JH, Han KH, Kwak JY 2014 Can ultrasound be as a surrogate marker for diagnosing a papillary thyroid cancer? Comparison with BRAF mutation analysis. Yonsei Med J 55:871-878.

25. Seo JY, Kim EK, Kwak JY 2014 Additional BRAF mutation analysis may have additional diagnostic value in thyroid nodules with "suspicious for malignant" cytology alone even when the nodules do not show suspicious US features. Endocrine 47:283-289.

26. Shi Q, Ibrahim A, Herbert K, Carvin M, Randolph M, Post KM, Curless K, Chen S, Cramer HM, Cheng L, Wu HH 2015 Detection of BRAF mutations on direct smears of thyroid fine-needle aspirates through cell transfer technique. Am J Clin Pathol 143:500-504.

27. Valderrabano P, Khazai L, Thompson ZJ, Otto KJ, Hallanger-Johnson JE, Chung CH, Centeno BA, McIver B 2018 Association of tumor size with histologic and clinical outcomes among patients with cytologically indeterminate thyroid nodules. JAMA Otolaryngol Head Neck Surg 144: 788-795.

28. Yeo MK, Liang ZL, Oh T, Moon Y, An S, Kim MK, Kim KS, Shong M, Kim JM, Jo YS 2011 Pyrosequencing cut-off value identifying $\mathrm{BRAF}^{\mathrm{V} 600 \mathrm{E}}$ mutation in fine needle aspiration samples of thyroid nodules. Clin Endocrinol (Oxf) 75:555-560.

29. Zatelli MC, Trasforini G, Leoni S, Frigato G, Buratto M, Tagliati F, Rossi R, Cavazzini L, Roti E, degli Uberti EC 2009 BRAF V600E mutation analysis increases diagnostic accuracy for papillary thyroid carcinoma in fine-needle aspiration biopsies. Eur J Endocrinol 161:467-473.

30. Danilovic DL, Lima EU, Domingues RB, Brandao LG, Hoff AO, Marui S 2014 Pre-operative role of BRAF in the guidance of the surgical approach and prognosis of differentiated thyroid carcinoma. Eur J Endocrinol 170:619-625.

31. Wei Y, Zhou X, Liu S, Wang H, Liu L, Liu R, Kang J, Hong K, Wang D, Yuan G 2016 Novel and practical scoring systems for the diagnosis of thyroid nodules. PLoS One 11:e0163039.

32. Shrestha RT, Evasovich MR, Amin K, Radulescu A, Sanghvi TS, Nelson AC, Shahi M, Burmeister LA 2016 Correlation between histological diagnosis and mutational panel testing of thyroid nodules: a two-year institutional experience. Thyroid 26:1068-1076.

33. Medici M, Kwong N, Angell TE, Marqusee E, Kim MI, Frates MC, Benson CB, Cibas ES, Barletta JA, Krane JF, Ruan DT, Cho NL, Gawande AA, Moore FD, Jr., Alexander EK 2015 The variable phenotype and low-risk nature of RAS-positive thyroid nodules. BMC Med 13:184.

34. Patel SG, Carty SE, McCoy KL, Ohori NP, LeBeau SO, Seethala RR, Nikiforova MN, Nikiforov YE, Yip L 2017 Preoperative detection of RAS mutation may guide extent of thyroidectomy. Surgery 161:168-175.

35. Radkay LA, Chiosea SI, Seethala RR, Hodak SP, LeBeau SO, Yip L, McCoy KL, Carty SE, Schoedel KE, Nikiforova MN, Nikiforov YE, Ohori NP 2014 Thyroid nodules with KRAS mutations are different from nodules with NRAS and HRAS mutations with regard to cytopathologic and histopathologic outcome characteristics. Cancer Cytopathol 122:873-882.

36. Guan H, Matonis D, Toraldo G, Lee SL 2018 Clinical significance of thyroid-stimulating hormone receptor gene mutations and/or sodium-iodine symporter gene overexpression in indeterminate thyroid fine needle biopsies. Front Endocrinol (Lausanne) 9:566.

37. Maerki J, Klein M, Chau K, Gimenez C, Fishbein J, Khutti S, Das K 2019 Determining the molecular test for indeterminate thyroid nodules best suited for our practice: a quality assurance study. Diagn Cytopathol 47:259-267.

38. Mon SY, Riedlinger G, Abbott CE, Seethala R, Ohori NP, Nikiforova MN, Nikiforov YE, Hodak SP 2018 Cancer risk and clinicopathological characteristics of thyroid nodules harboring thyroid-stimulating hormone receptor gene mutations. Diagn Cytopathol 46:369-377.

39. Dujardin F, Pages JC, Collin C, de Calan L, Lecomte P, Guyetant S 2010 [BRAF V600E mutation in papillary thyroid carcinoma: prevalence and detection in fine needle aspiration specimens]. Ann Pathol 30:252-262.

40. Guerra A, Carrano M, Angrisani E, Vitale M 2013 [Diagnostic value of $\mathrm{BRAF}^{\mathrm{V} 600 \mathrm{E}}$ and RET/PTC oncogenes in thyroid nodule aspirates]. Recenti Prog Med 104:415-419.

41. Wan H, Zhang B, Wang Y, Xiao T, Guo H, Liu W, Yan D, $\mathrm{Xu}$ Z, Tang P 2014 [Clinical role of BRAF V600E mutation testing in thyroid nodules]. Zhonghua Er Bi Yan Hou Tou Jing Wai Ke Za Zhi 49:468-472.

42. Ferraz C, Rehfeld C, Krogdahl A, Precht Jensen EM, Bosenberg E, Narz F, Hegedus L, Paschke R, Eszlinger M 2012 Detection of PAX8/PPARG and RET/PTC rearrangements is feasible in routine air-dried fine needle aspiration smears. Thyroid 22:1025-1030.

43. Guerra A, Sapio MR, Marotta V, Campanile E, Moretti MI, Deandrea M, Motta M, Limone PP, Fenzi G, Rossi G, Vitale M 2011 Prevalence of RET/PTC rearrangement in benign and malignant thyroid nodules and its clinical application. Endocr J 58:31-38.

44. Lowry R. VassarStats: website for statistical computation. Available at http://vassarstats.net/index.html (accessed March 10, 2019).

45. Jang EK, Kim WG, Kim EY, Kwon H, Choi YM, Jeon MJ, Baek JH, Lee JH, Kim TY, Shong YK, Choi J, Song DE, Kim WB 2016 Usefulness of NRAS codon 61 mutation analysis and core needle biopsy for the diagnosis of thyroid nodules previously diagnosed as atypia of undetermined significance. Endocrine 52:305-312.

46. Censi S, Cavedon E, Bertazza L, Galuppini F, Watutantrige-Fernando S, De Lazzari P, Nacamulli D, Pennelli G, Fassina A, Iacobone M, Casal Ide E, Vianello F, Barollo S, Mian C 2017 Frequency and significance of Ras, Tert promoter, and Braf mutations in cytologically indeterminate thyroid nodules: a monocentric case series at a tertiary-level endocrinology unit. Front Endocrinol (Lausanne) 8:273.

47. Eszlinger M, Bohme K, Ullmann M, Gorke F, Siebolts U, Neumann A, Franzius C, Adam S, Molwitz T, Landvogt C, Amro B, Hach A, Feldmann B, Graf D, Wefer A, Niemann R, Bullmann C, Klaushenke G, Santen R, Tonshoff G, Ivancevic V, Kogler A, Bell E, Lorenz B, Kluge G, Hartenstein C, Ruschenburg I, Paschke R 2017 Evaluation of a two-year routine application of molecular testing of thyroid fine-needle aspirations using a seven-gene panel in a primary referral setting in Germany. Thyroid 27:402-411.

48. Livhits MJ, Kuo EJ, Leung AM, Rao J, Levin M, Douek ML, Beckett KR, Zanocco KA, Cheung DS, Gofnung YA, Smooke-Praw S, Yeh MW 2018 Gene expression classifier vs targeted next-generation sequencing in the management of indeterminate thyroid nodules. J Clin Endocrinol Metab 103:2261-2268. 
49. Nikiforov YE, Carty SE, Chiosea SI, Coyne C, Duvvuri U, Ferris RL, Gooding WE, LeBeau SO, Ohori NP, Seethala RR, Tublin ME, Yip L, Nikiforova MN 2015 Impact of the multi-gene ThyroSeq next-generation sequencing assay on cancer diagnosis in thyroid nodules with atypia of undetermined significance/follicular lesion of undetermined significance cytology. Thyroid 25:1217-1223.

50. Nikiforov YE, Carty SE, Chiosea SI, Coyne C, Duvvuri U, Ferris RL, Gooding WE, Hodak SP, LeBeau SO, Ohori NP, Seethala RR, Tublin ME, Yip L, Nikiforova MN 2014 Highly accurate diagnosis of cancer in thyroid nodules with follicular neoplasm/suspicious for a follicular neoplasm cytology by ThyroSeq v2 next-generation sequencing assay. Cancer 120:3627-3634.

51. Eszlinger M, Piana S, Moll A, Bosenberg E, Bisagni A, Ciarrocchi A, Ragazzi M, Paschke R 2015 Molecular testing of thyroid fine-needle aspirations improves presurgical diagnosis and supports the histologic identification of minimally invasive follicular thyroid carcinomas. Thyroid 25:401-409.

52. Giusti M, Massa B, Balestra M, Calamaro P, Gay S, Schiaffino S, Turtulici G, Zupo S, Monti E, Ansaldo G 2017 Retrospective cytological evaluation of indeterminate thyroid nodules according to the British Thyroid Association 2014 classification and comparison of clinical evaluation and outcomes. J Zhejiang Univ Sci B 18:555-566.

53. Taye A, Gurciullo D, Miles BA, Gupta A, Owen RP, Inabnet WB, 3rd, Beyda JN, Marti JL 2018 Clinical performance of a next-generation sequencing assay (ThyroSeq v2) in the evaluation of indeterminate thyroid nodules. Surgery 163:97-103.

54. Decaussin-Petrucci M, Descotes F, Depaepe L, Lapras V, Denier ML, Borson-Chazot F, Lifante JC, Lopez J 2017 Molecular testing of BRAF, RAS and TERT on thyroid FNAs with indeterminate cytology improves diagnostic accuracy. Cytopathology 28:482-487.

55. Valderrabano P, Khazai L, Thompson ZJ, Leon ME, Otto KJ, Hallanger-Johnson JE, Wadsworth JT, Chung CH, Centeno BA, McIver B 2018 Impact of oncogene panel results on surgical management of cytologically indeterminate thyroid nodules. Head Neck 40:1812-1823.

56. Witt RL 2016 Targeted next generation sequencing with ThyroSeq v2.1 for indeterminate thyroid nodules in clinical practice. Del Med J 88:366-372.

57. An JH, Song KH, Kim SK, Park KS, Yoo YB, Yang JH, Hwang TS, Kim DL 2015 RAS mutations in indeterminate thyroid nodules are predictive of the follicular variant of papillary thyroid carcinoma. Clin Endocrinol (Oxf) 82: 760-766.

58. Bongiovanni M, Molinari F, Eszlinger M, Paschke R, Barizzi J, Merlo E, Giovanella L, Fasolini F, Cattaneo F, Ramelli F, Mazzucchelli L, Frattini M 2015 Laser capture microdissection is a valuable tool in the preoperative molecular screening of follicular lesions of the thyroid: an institutional experience. Cytopathology 26:288-296.

59. Stence AA, Gailey MP, Robinson RA, Jensen CS, Ma D 2015 Simultaneously detection of 50 mutations at 20 sites in the BRAF and RAS genes by multiplexed singlenucleotide primer extension assay using fine-needle aspirates of thyroid nodules. Yale J Biol Med 88:351-358.

60. Partyka KL, Randolph ML, Lawrence KA, Cramer H, Wu HH 2018 Utilization of direct smears of thyroid fine-needle aspirates for ancillary molecular testing: a comparison of two proprietary testing platforms. Diagn Cytopathol 46:320-325.
61. Liu S, Gao A, Zhang B, Zhang Z, Zhao Y, Chen P, Ji M, Hou P, Shi B 2014 Assessment of molecular testing in fineneedle aspiration biopsy samples: an experience in a Chinese population. Exp Mol Pathol 97:292-297.

62. Moses W, Weng J, Sansano I, Peng M, Khanafshar E, Ljung BM, Duh QY, Clark OH, Kebebew E 2010 Molecular testing for somatic mutations improves the accuracy of thyroid fine-needle aspiration biopsy. World J Surg 34: 2589-2594.

63. Rivas AM, Nassar A, Zhang J, Casler JD, Chindris AM, Smallridge R, Bernet V 2018 ThyroSeq((R))V2.0 molecular testing: a cost-effective approach for the evaluation of indeterminate thyroid nodules. Endocr Pract 24:780-788.

64. Biron VL, Matkin A, Kostiuk M, Williams J, Cote DW, Harris J, Seikaly H, O'Connell DA 2018 Analytic and clinical validity of thyroid nodule mutational profiling using droplet digital polymerase chain reaction. J Otolaryngol Head Neck Surg 47:60.

65. Beaudenon-Huibregtse S, Alexander EK, Guttler RB, Hershman JM, Babu V, Blevins TC, Moore P, Andruss B, Labourier E 2014 Centralized molecular testing for oncogenic gene mutations complements the local cytopathologic diagnosis of thyroid nodules. Thyroid 24:1479-1487.

66. Mancini I, Pinzani P, Pupilli C, Petrone L, De Feo ML, Bencini L, Pazzagli M, Forti G, Orlando C 2012 A highresolution melting protocol for rapid and accurate differential diagnosis of thyroid nodules. J Mol Diagn 14: 501-509.

67. Nikiforov YE, Steward DL, Robinson-Smith TM, Haugen BR, Klopper JP, Zhu Z, Fagin JA, Falciglia M, Weber K, Nikiforova MN 2009 Molecular testing for mutations in improving the fine-needle aspiration diagnosis of thyroid nodules. J Clin Endocrinol Metab 94:2092-2098.

68. Nikiforov YE, Ohori NP, Hodak SP, Carty SE, LeBeau SO, Ferris RL, Yip L, Seethala RR, Tublin ME, Stang MT, Coyne C, Johnson JT, Stewart AF, Nikiforova MN 2011 Impact of mutational testing on the diagnosis and management of patients with cytologically indeterminate thyroid nodules: a prospective analysis of 1056 FNA samples. J Clin Endocrinol Metab 96:3390-3397.

69. Macerola E, Rago T, Proietti A, Basolo F, Vitti P 2019 The mutational analysis in the diagnostic work-up of thyroid nodules: the real impact in a center with large experience in thyroid cytopathology. J Endocrinol Invest 42:157-166.

70. Bellevicine C, Sgariglia R, Migliatico I, Vigliar E, D’Anna M, Nacchio MA, Serra N, Malapelle U, Bongiovanni M, Troncone G 2018 Different qualifiers of AUS/FLUS thyroid FNA have distinct BRAF, RAS, RET/PTC, and PAX8/ PPARg alterations. Cancer Cytopathol 126:317-325.

71. Adeniran AJ, Hui P, Chhieng DC, Prasad ML, Schofield K, Theoharis C 2011 BRAF mutation testing of thyroid fineneedle aspiration specimens enhances the predictability of malignancy in thyroid follicular lesions of undetermined significance. Acta Cytol 55:570-575.

72. Agretti P, Niccolai F, Rago T, De Marco G, Molinaro A, Scutari M, Di Cosmo C, Di Coscio G, Vitale M, Maccheroni M, Vitti P, Tonacchera M 2014 BRAF mutation analysis in thyroid nodules with indeterminate cytology: our experience on surgical management of patients with thyroid nodules from an area of borderline iodine deficiency. J Endocrinol Invest 37:1009-1014.

73. Beisa A, Kvietkauskas M, Beisa V, Stoskus M, Ostaneviciute E, Jasiunas E, Griskevicius L, Strupas K 2017 The utility of the Bethesda category and its association with 
BRAF mutation in the prediction of papillary thyroid cancer stage. Langenbecks Arch Surg 402:227-234.

74. Canadas-Garre M, Becerra-Massare P, Lopez de la Torre-Casares M, Villar-del Moral J, Cespedes-Mas S, Vilchez-Joya R, Muros-de Fuentes T, Garcia-Calvente C, Piedrola-Maroto G, Lopez-Nevot MA, Montes-Ramirez R, Llamas-Elvira JM 2012 Reduction of false-negative papillary thyroid carcinomas by the routine analysis of BRAF(T1799A) mutation on fine-needle aspiration biopsy specimens: a prospective study of 814 thyroid FNAB patients. Ann Surg 255:986-992.

75. Jeong SH, Hong HS, Lee EH, Cha JG, Park JS, Kwak JJ 2013 Outcome of thyroid nodules characterized as atypia of undetermined significance or follicular lesion of undetermined significance and correlation with Ultrasound features and BRAF(V600E) mutation analysis. AJR Am J Roentgenol 201:W854-W860.

76. Jo YS, Huang S, Kim YJ, Lee IS, Kim SS, Kim JR, Oh T, Moon Y, An S, Ro HK, Kim JM, Shong M 2009 Diagnostic value of pyrosequencing for the BRAF V600E mutation in ultrasound-guided fine-needle aspiration biopsy samples of thyroid incidentalomas. Clin Endocrinol (Oxf) 70:139-144.

77. Johnson SJ, Hardy SA, Roberts C, Bourn D, Mallick U, Perros P 2014 Pilot of BRAF mutation analysis in indeterminate, suspicious and malignant thyroid FNA cytology. Cytopathology 25:146-154.

78. Kim TH, Jeong DJ, Hahn SY, Shin JH, Oh YL, Ki CS, Kim JW, Jang JY, Cho YY, Chung JH, Kim SW 2016 Triage of patients with AUS/FLUS on thyroid cytopathology: effectiveness of the multimodal diagnostic techniques. Cancer Med 5:769-777.

79. Kloos RT, Reynolds JD, Walsh PS, Wilde JI, Tom EY, Pagan M, Barbacioru C, Chudova DI, Wong M, Friedman L, LiVolsi VA, Rosai J, Lanman RB, Kennedy GC 2013 Does addition of BRAF V600E mutation testing modify sensitivity or specificity of the Afirma gene expression classifier in cytologically indeterminate thyroid nodules? J Clin Endocrinol Metab 98:E761-E768.

80. Kowalska A, Kowalik A, Palyga I, Walczyk A, GasiorPerczak D, Kopczynski J, Lizis-Kolus K, Szyska-Skrobot D, Hurej S, Radowicz-Chil A, Chodurska R, Wypiorkiewicz E, Chlopek M, Nowak E, Niemyska K, Gozdz S 2016 The usefulness of determining the presence of BRAF V600E mutation in fine-needle aspiration cytology in indeterminate cytological results. Endokrynol Pol 67:41-47.

81. Lee ST, Kim SW, Ki CS, Jang JH, Shin JH, Oh YL, Kim JW, Chung JH 2012 Clinical implication of highly sensitive detection of the BRAF V600E mutation in fine-needle aspirations of thyroid nodules: a comparative analysis of three molecular assays in 4585 consecutive cases in a BRAF V600E mutation-prevalent area. J Clin Endocrinol Metab 97:2299-2306.

82. Marino M, Monzani ML, Brigante G, Cioni K, Madeo B, Santi D, Maiorana A, Bettelli S, Moriondo V, Pignatti E, Bonacini L, Carani C, Rochira V, Simoni M 2015 Highresolution melting is a sensitive, cost-effective, time-saving technique for BRAF V600E detection in thyroid FNAB washing liquid: a prospective cohort study. Eur Thyroid J 4:73-81.

83. Park HJ, Moon JH, Yom CK, Kim KH, Choi JY, Choi SI, Ahn SH, Jeong WJ, Lee WW, Park SY 2014 Thyroid "atypia of undetermined significance" with nuclear atypia has high rates of malignancy and BRAF mutation. Cancer Cytopathol 122:512-520.

84. Pelizzo MR, Boschin IM, Barollo S, Pennelli G, Toniato A, Zambonin L, Vianello F, Piotto A, Ide EC, Pagetta C, Sorgato N, Torresan F, Girelli ME, Nacamulli D, Mantero F, Mian C 2011 BRAF analysis by fine needle aspiration biopsy of thyroid nodules improves preoperative identification of papillary thyroid carcinoma and represents a prognostic factor. A mono-institutional experience. Clin Chem Lab Med 49:325-329.

85. Rho M, Kim EK, Moon HJ, Yoon JH, Park VY, Han K, Kwak JY 2017 Clinical parameter for deciding the BRAF $^{\mathrm{V} 600 \mathrm{E}}$ mutation test in atypia of undetermined significance/follicular lesion of undetermined significance thyroid nodules: US features according to TIRADS. U1trasound Q 33:284-288.

86. Rossi M, Lupo S, Rossi R, Franceschetti P, Trasforini G, Bruni S, Tagliati F, Buratto M, Lanza G, Damiani L, Degli Uberti E, Zatelli MC 2017 Proposal for a novel management of indeterminate thyroid nodules on the basis of cytopathological subclasses. Endocrine 57:98-107.

87. Seo JW, Jang AL, Suh SH, Park HS, Kang MK, Hong JC 2017 Atypia of undetermined significance on thyroid fine needle aspiration-risk factors for malignancy. Clin Otolaryngol 42:234-238.

88. Kim DS, Kim DW, Heo YJ, Baek JW, Lee YJ, Choo HJ, Park YM, Park HK, Ha TK, Kim DH, Jung SJ, Park JS, Ahn KJ, Baek HJ, Kang T 2018 Utility of including BRAF mutation analysis with ultrasonographic and cytological diagnoses in ultrasonography-guided fine-needle aspiration of thyroid nodules. PLoS One 13:e0202687.

89. Swierniak M, Pfeifer A, Stokowy T, Rusinek D, Chekan M, Lange D, Krajewska J, Oczko-Wojciechowska M, Czarniecka A, Jarzab M, Jarzab B, Wojtas B 2016 Somatic mutation profiling of follicular thyroid cancer by next generation sequencing. Mol Cell Endocrinol 433:130-137.

90. Clinkscales W, Ong A, Nguyen S, Harruff EE, Gillespie MB 2017 Diagnostic value of RAS mutations in indeterminate thyroid nodules. Otolaryngol Head Neck Surg 156: 472-479.

91. Nabhan F, Porter K, Lupo MA, Randolph GW, Patel KN, Kloos RT 2018 Heterogeneity in positive predictive value of RAS mutations in cytologically indeterminate thyroid nodules. Thyroid 28:729-738.

92. Ali SZ, Siperstein A, Sadow PM, Golding AC, Kennedy GC, Kloos RT, Ladenson PW 2019 Extending expressed RNA genomics from surgical decision making for cytologically indeterminate thyroid nodules to targeting therapies for metastatic thyroid cancer. Cancer Cytopathol. [Epub ahead of print]; DOI: 10.1002/cncy.22132.

Address correspondence to: Whitney S. Goldner, MD

Division of Diabetes, Endocrinology, and Metabolism Department of Internal Medicine University of Nebraska Medical Center 984120 Nebraska Medical Center Omaha, NE 68198-4120

E-mail: wgoldner@unmc.edu 